\title{
Quantitative 7T MRI does not detect occult brain damage in neuromyelitis optica
}

Baptiste Pasquier, Nadja Borisow, MD, Ludwig Rasche, MD, Judith Bellmann-Strobl, MD, Klemens Ruprecht, MD, Thoralf Niendorf, MD, PHD, Tobias J. Derfuss, MD, Jens Wuerfel, MD, Friedemann Paul, MD,* and Tim Sinnecker, MD*

Neurol Neuroimmunol Neuroinflamm 2019;6:e541. doi:10.1212/NXI.0000000000000541

\section{Abstract}

\section{Objective}

To investigate and compare occult damages in aquaporin-4 (AQP4)-rich periependymal regions in patients with neuromyelitis optica spectrum disorder (NMOSD) vs healthy controls (HCs) and patients with multiple sclerosis (MS) applying quantitative T1 mapping at 7 Tesla $(\mathrm{T})$ in a cross-sectional study.

\section{Methods}

Eleven patients with NMOSD (median Expanded Disability Status Scale [EDSS] score 3.5, disease duration 9.3 years, age 43.7 years, and 11 female) seropositive for anti-AQP4 antibodies, 7 patients with MS (median EDSS score 1.5, disease duration 3.6, age 30.2 years, and 4 female), and $10 \mathrm{HCs}$ underwent $7 \mathrm{~T}$ MRI. The imaging protocol included $\mathrm{T} 2{ }^{*}$-weighted $(\mathrm{w})$ imaging and an MP2RAGE sequence yielding 3D T1w images and quantitative T1 maps. We semiautomatically marked the lesion-free periependymal area around the cerebral aqueduct and the lateral, third, and fourth ventricles to finally measure and compare the $\mathrm{T} 1$ relaxation time within these areas.

\section{Results}

We did not observe any differences in the T1 relaxation time between patients with NMOSD and HCs (all $p>0.05$ ). Contrarily, the T1 relaxation time was longer in patients with MS vs patients with NMOSD (lateral ventricle $p=0.056$, third ventricle $p=0.173$, fourth ventricle $p=$ 0.016 , and cerebral aqueduct $p=0.048$ ) and vs HCs (third ventricle $p=0.027$, fourth ventricle $p$ $=0.013$, lateral ventricle $p=0.043$, and cerebral aqueduct $p=0.005$ ).

\section{Conclusion}

Unlike in MS, we did not observe subtle T1 changes in lesion-free periependymal regions in NMOSD, which supports the hypothesis of a rather focal than diffuse brain pathology in NMOSD.

\author{
Correspondence \\ Dr. Paul \\ friedemann.paul@charite.de
}




\section{Glossary}

AQP4 = aquaporin-4; DTI = diffusion tensor imaging; EDSS = Expanded Disability Status Scale; FLAIR = fluid-attenuated inversion recovery; HC = healthy control; MRS = MR spectroscopy; NAA = N-acetylaspartic acid; NAWM = normal-appearing white matter; NMOSD = neuromyelitis optica spectrum disorder; RRMS = relapsing-remitting multiple sclerosis; TE = echo time; $\mathbf{T I}=$ inversion time; $\mathbf{T R}=$ repetition time.

Neuromyelitis optica spectrum disorder (NMOSD) is a severe and often devastating autoimmune and inflammatory CNS disease frequently associated with autoantibodies targeting aquaporin-4 (AQP4) water channels leading to complement activation and focal lesions within AQP4-rich CNS areas such as the spinal cord, the optic nerves, and periependymal regions. ${ }^{1,2}$ In more detail, brain AQP4 water channels are predominantly located within astrocyte foot processes in the glial limiting membrane and in the basolateral cell plasma membrane of ependymal cells. $^{3,4}$

Clinical, ${ }^{5} \mathrm{MRI},{ }^{6}$ and optical coherence tomography findings mirror the anatomic distribution of AQP4 water channels within the CNS. ${ }^{7-9}$ MRI is used to rule out other disorders and to visualize optic neuritis and signs of myelitis. ${ }^{6}$ On top of that, brain lesion patterns typical for NMOSD have been described including extensive or tumefactive periventricular lesions around the lateral, third, and fourth ventricles and the cerebral aqueduct affecting, e.g., diencephalic structures, the area postrema, the thalamus, the hypothalamus, the corpus callosum, or the periventricular white matter. ${ }^{6}$ Nevertheless, NMOSD-specific brain MRI abnormalities are only detectable within a small proportion of patients, ${ }^{10}$ and many patients with NMOSD present with a normal brain MRI, ${ }^{11}$ which in the past has led to the inclusion of "negative brain MRI at onset" to the 2006 Wingerchuk diagnostic criteria. ${ }^{12}$

Quantitative MRI allows for the quantification of physical variables such as the $\mathrm{T} 1$ relaxation time that is sensitive to freewater protons and structural damage to finally compare those variables between tissue regions or participants. When combining quantitative MR techniques with ultra-high-field MRI at 7 Tesla that benefits from an increased signal-to-noise ratio, even subtle degenerative or inflammatory changes that are not obviously present on standard MR images can be assessed. ${ }^{13,14}$

On this background, we here prospectively performed quantitative $\mathrm{T} 1$ relaxometry at $7 \mathrm{~T}$ to search for occult brain damage within the AQP4-rich, lesion-free and normalappearing periependymal white or gray matter of patients with NMOSD. We compared our results with those in healthy controls (HCs) and patients with multiple sclerosis (MS).

\section{Methods}

\section{Participants}

Eleven patients with NMOSD as defined by the 2015 international consensus diagnostic criteria $^{1}$ were prospectively recruited from the outpatient clinic of the department of neurology, Charité-Universitätsmedizin Berlin between January 2014 and December 2015. For comparison, 10 age-matched HCs and 7 patients with relapsing-remitting MS (RRMS), which were best comparable regarding age and sex, were selected from the NeuroCure neuroimaging database as controls. AQP4 antibody serostatus was assessed in patients with NMOSD using one of several established assays. ${ }^{15-17}$ Antibodies against AQP4 were present in all patients with NMOSD. Clinical disability was assessed using the Expanded Disability Status Scale (EDSS) in patients with MS and NMOSD.

\section{Standard protocol approvals, registrations, and patient consents}

The Ethics Committee of the Charité-Universitätsmedizin Berlin in conformity with the Declaration of Helsinki approved the study (EA 1/054/09). All participants provided written informed consent.

\section{MRI acquisition}

Ultra-high-field MR images were acquired using a 7T Siemens whole-body scanner (Magnetom; Siemens, Erlangen, Germany) and a 24-channel receive head coil (Nova Medical, Wilmington, MA) equipped with a birdcage volume coil for transmission. The imaging protocol included 2-dimensional $\mathrm{T} 2{ }^{*}$-weighted fast low angle shot $\left(\mathrm{T} 2^{*} \mathrm{w}\right.$ FLASH; echo time $[\mathrm{TE}]=25.0 \mathrm{~ms}$, repetition time $[\mathrm{TR}]=$ $1,820 \mathrm{~ms}$; spatial resolution $=[0.5 \times 0.5 \times 2] \mathrm{mm}^{3}$, supratentorial coverage) and 3-dimensional fluid-attenuated in version recovery (FLAIR, TE $=90 \mathrm{~ms}$; $\mathrm{TR}=16,000 \mathrm{~ms}$; inversion time $[\mathrm{TI}]=2,925 \mathrm{~ms}$, spatial resolution $=[1.0 \times$ $1.0 \times 3.0] \mathrm{mm}^{3}$ ).

A 3-dimensional T1-weighted magnetization-prepared rapid gradient-echo sequence with 2 TIs (T1w MP2RAGE, $\mathrm{TE}=2.98 \mathrm{~ms}$; $\mathrm{TR}=2,300 \mathrm{~ms}$; $\mathrm{TI}=900 \mathrm{~ms}$; spatial resolution $=(1.0 \times 1.0 \times 1.0) \mathrm{mm}^{3}$, whole-brain coverage) was used to generate bias-field corrected $\mathrm{T} 1 \mathrm{w}$ images and quantitative T1 maps. Phantom experiments have shown that $\mathrm{T} 1$ relaxation times measured using the MP2RAGE approach are closely correlated in a linear fashion with true T1 physical values commonly observed within the brain. ${ }^{18}$

\section{Image analysis}

All images were analyzed and processed using 3D Slicer (Version 4.6.2 on MacOS 10.11.4, The Slicer Community), 
Table 1 Anatomic boundaries for segmentation

\begin{tabular}{|c|c|c|c|c|c|c|}
\hline \multirow{2}{*}{$\begin{array}{l}\text { Name of } \\
\text { the mask }\end{array}$} & \multicolumn{5}{|c|}{ Anatomic boundaries of the mask } & \multirow{2}{*}{$\begin{array}{l}\text { Structures within the } \\
\text { mask }\end{array}$} \\
\hline & Anterior & Posterior & Superior & Inferior & Medial & \\
\hline \multirow[t]{6}{*}{$\begin{array}{l}\text { Lateral } \\
\text { ventricle }\end{array}$} & Anterior horn & Posterior horn & $\begin{array}{l}\text { Body of the lateral } \\
\text { ventricle }\end{array}$ & $\begin{array}{l}\text { End of the anterior } \\
\text { horn }\end{array}$ & $\begin{array}{l}\text { Septum } \\
\text { pellucidum }\end{array}$ & $\begin{array}{l}\text { Audate nucleus, Genu of } \\
\text { corpus callosum }\end{array}$ \\
\hline & Corpus callosum & & & $\begin{array}{l}\text { End of the posterior } \\
\text { horn }\end{array}$ & $\begin{array}{l}\text { Interventricular } \\
\text { foramen }\end{array}$ & $\begin{array}{l}\text { Splenium of corpus } \\
\text { callosum }\end{array}$ \\
\hline & & & & $\begin{array}{l}\text { Inferior horn until } \\
\text { collateral trigone }\end{array}$ & & Forceps minor \\
\hline & & & & & & Tapetum \\
\hline & & & & & & $\begin{array}{l}\text { Inferior fronto-occipital } \\
\text { fasciculus }\end{array}$ \\
\hline & & & & & & Optic radiation \\
\hline \multirow[t]{4}{*}{$\begin{array}{l}\text { Third } \\
\text { ventricle }\end{array}$} & Lamina terminalis & $\begin{array}{l}\text { Quadrigeminal } \\
\text { cistern }\end{array}$ & $\begin{array}{l}\text { Beginning of the } \\
\text { third ventricle }\end{array}$ & Cerebral aqueduct & $\begin{array}{l}\text { Interthalamic } \\
\text { adhesion }\end{array}$ & Thalamus \\
\hline & $\begin{array}{l}\text { Cistern of the } \\
\text { lamina terminalis }\end{array}$ & $\begin{array}{l}\text { Posterior } \\
\text { commissure }\end{array}$ & & & & Anterior commissure \\
\hline & $\begin{array}{l}\text { Interventricular } \\
\text { foramina }\end{array}$ & Pineal gland & & & & Posterior commissure \\
\hline & & & & & & Fornix \\
\hline \multirow[t]{2}{*}{$\begin{array}{l}\text { Fourth } \\
\text { ventricle }\end{array}$} & Rhomboid fossa & Cerebellum & $\begin{array}{l}\text { Superior medullary } \\
\text { velum }\end{array}$ & Inferior cerebellar & Nodulus & $\begin{array}{l}\text { Medial longitudinal } \\
\text { fasciculus }\end{array}$ \\
\hline & $\begin{array}{l}\text { Bottom of the } \\
\text { fourth ventricle }\end{array}$ & & Fastigium & Peduncle & & $\begin{array}{l}\text { Superior cerebellar } \\
\text { peduncle }\end{array}$ \\
\hline \multirow[t]{2}{*}{$\begin{array}{l}\text { Cerebral } \\
\text { aqueduct }\end{array}$} & & & $\begin{array}{l}\text { Opening of the } \\
\text { cerebral aqueduct }\end{array}$ & $\begin{array}{l}\text { Entry in the fourth } \\
\text { ventricle }\end{array}$ & & $\begin{array}{l}\text { Periaqueductal gray } \\
\text { matter }\end{array}$ \\
\hline & & & & & & Inferior colliculus \\
\hline
\end{tabular}

The table provides an overview on the anatomic boundaries that were used for segmentation of the ventricles.

and fslmaths integrated in the FMRIB Software Library (FSL, version 5.0, FMRIB, Oxford, United Kingdom).

To semiautomatically segment periependymal regions, we defined regions of interest (table 1) and applied a 5-step procedure (figure 1).
First, the lateral, third, and fourth ventricles and the cerebral aqueducts were segmented in consensus reading by a trained and blinded investigator (B.P.) using a semiautomatic threshold-based approach with best visual correction on $\mathrm{T} 1 \mathrm{w}$ images. Next, the border of all regions of interest was automatically dilated by $1 \mathrm{~mm}$ to avoid partial volume effects of

Figure 1 Segmentation of the normal-appearing periependymal white matter

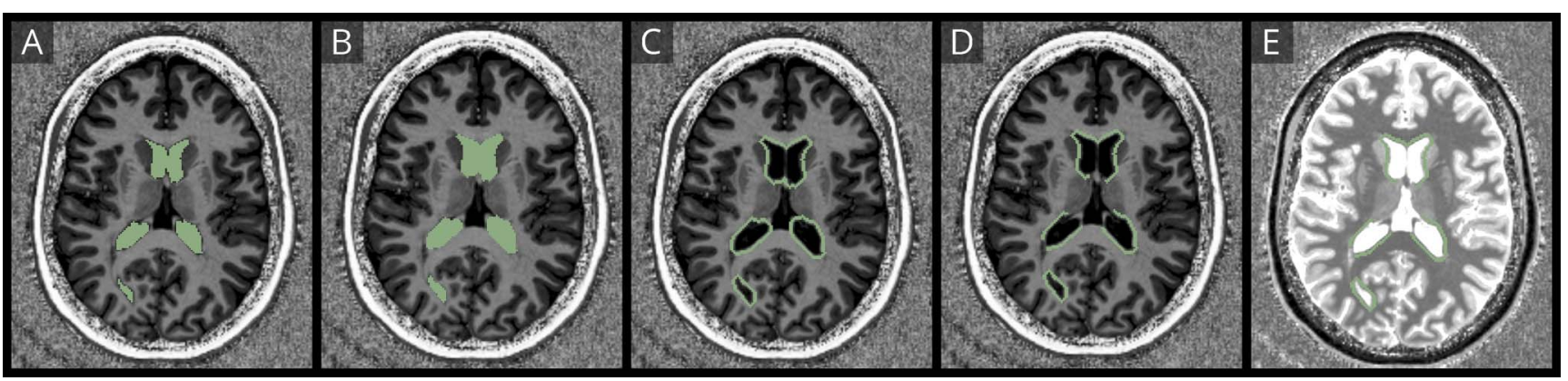

The figure demonstrates the procedure to segment the normal-appearing periependymal white matter. First, the ventricles were segmented (A) and dilated by $1 \mathrm{~mm}$ to avoid partial volume effects and $2 \mathrm{~mm}$ to include the periependymal white matter (B). Second, the 1-mm dilated ventricle mask was subtracted from the $1+2 \mathrm{~mm}$ dilated ventricle mask (C). Finally, the periependymal mask was manually edited for smaller errors, and the lesion mask was subtracted (D) to overlay the final mask with T1 maps (E). 


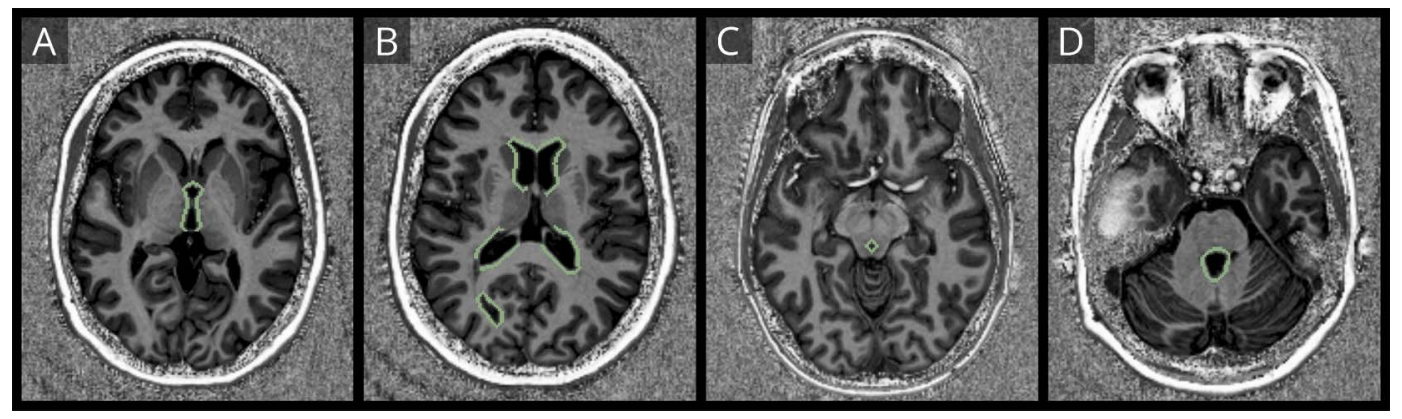

The figure demonstrates exemplary masks of segmented periependymal regions around the third ventricle (A), the lateral ventricles (B), the cerebral aqueduct (C), and the fourth ventricle (D).

the CSF on the final analysis. Third, the border of all regions of interest was automatically dilated by $2 \mathrm{~mm}$, and the $1-\mathrm{mm}$ dilated mask was then subtracted from the $3-\mathrm{mm}$ dilated mask. This step hence creates a 2 -mm-thick small rim around the ventricles, which represents the periependymal white matter. Fourth, T1 hypointense and FLAIR/T2*w hyperintense white matter lesions were manually segmented to subtract the lesion map from previously created region-specific periependymal masks. Finally, periependymal masks of the lateral ventricles were split into white and (cortical and deep) gray matter areas by applying T1-threshold-based approach with best visual correction.

The region-specific, CSF-free, lesion-free, and 2-mm-thick periependymal region masks were then used to calculate the mean $\mathrm{T} 1$ relaxation time per region and participant using the Label Statistics Module integrated in 3D Slicer (figure 2).

In addition, the lesion count was assessed on $\mathrm{T} 2{ }^{*} \mathrm{w}$ images. Hereby, all $\mathrm{T}^{*}{ }^{*}$ hyperintense lesions larger than $2 \mathrm{~mm}$ were counted.

\section{Statistical analysis}

All analyses were performed using IBM SPSS Statistics (version 20, IBM, Somers, NY). Normal distribution was assessed visually and by using a Shapiro-Wilk test. T1 measures around the third ventricle, the fourth ventricle, the cerebral aqueduct, and the lateral ventricle (gray matter) were normally distributed. Thus, the Student $t$ test was used to assess group differences in mean $\mathrm{T} 1$ between patients with NMOSD, MS, and HCs. T1 measures around the lateral ventricle were not normally distributed. Thus, Mann-Whitney $U$ test was used to assess group differences in mean $\mathrm{T} 1$ (lateral ventricle) between patients with NMOSD, MS, and HCs. Sex differences were assessed using the chi-squared test, and differences in age were assessed using the Student $t$ test. $p$-Values $<0.05$ were considered statistically significant. Given the exploratory nature of the study, no adjustments for multiple comparisons were made.

\section{Data availability}

This study was supported by a grant from the Guthy-Jackson Charitable Foundation, which supports the idea of data sharing to facilitate research in the field of NMOSD. Hence, deidentified 7T MRI data of patients with NMOSD included in this study will be shared by the corresponding author with qualified scientific collaborators for research projects on request.

\section{Results}

\section{Cohort description}

Eleven AQP4 antibody-positive patients with NMOSD and a mean \pm SD age of $43.7 \pm 7.12$ years (range 22-69 years) were included. Ten HCs (mean \pm SD age $41.6 \pm 11.8$ years, range 29-67 years) and 7 patients with RRMS (mean \pm SD age $30.2 \pm 7.9$ years, range 21.4 years) served as controls.

Patients with NMOSD had a total number of 154 (mean \pm SD $14 \pm 16.5$, range $0-55$ ) lesions. A total number of 143 lesions (mean \pm SD $20.4 \pm 17.4$, range $0-53$ ) were detectable in patients with MS. More clinical details including the EDSS score and sex are presented in table 2.

\section{$\mathrm{T} 1$ relaxation time of periependymal regions in healthy controls}

Table 3 gives an overview of all results. The mean $\mathrm{T} 1$ relaxation time of periependymal regions around the lateral ventricle in HCs was $1,355.6 \pm 49.3 \mathrm{~ms}$ (range 1,296.5-1,472.4 ms). Gray matter areas had a mean T1 relaxation time of $1772.9 \pm 23.1 \mathrm{~ms}$ (range 1741.9-1819.5 ms), whereas white matter areas had a mean T1 relaxation time of $1,220.9 \pm 53.8 \mathrm{~ms}$ (range $1,166.8-1,358.6 \mathrm{~ms})$.

Furthermore, we observed a mean T1 relaxation time of $1,534.7 \pm 47.5 \mathrm{~ms}$ (range 1,470.0-1,597.1 ms) of periependymal regions around the third ventricle, a mean T1 relaxation time of $1,359.2 \pm 25.5 \mathrm{~ms}$ (range 1,322.9-1,409.9 ms) of periependymal regions around the fourth ventricle, and a mean $\mathrm{T} 1$ relaxation 
Table 2 Cohort overview

\begin{tabular}{|c|c|c|c|}
\hline & $\mathrm{HC}$ & NMOSD & RRMS \\
\hline n (n, female, $p$ value) & $10(9)$ & $11(11), p=0.28$ & $7(4), p=0.12$ \\
\hline age (years, mean $\pm S D$, range, $p$ value) & $41.6 \pm 11.8,29-67$ & $43.7 \pm 14.2,22-69, p=0.71$ & $30.2 \pm 7.9,21-40, p=0.04$ \\
\hline $\begin{array}{l}\text { Disease duration } \\
\text { (y, mean } \pm S D, \text { range })\end{array}$ & NA & $9.3 \pm 8.1,1-29$ & $3.6 \pm 2.1,0.3-6.6$ \\
\hline EDSS (median, range) & NA & $3.5,1.5-5.0$ & $1.5,0-3.0$ \\
\hline
\end{tabular}

Abbreviations: NMOSD = neuromyelitis optica spectrum disorder; RRMS = relapsing-remitting MS; HC = healthy control; EDSS = Expanded Disability Status Scale; NA = not applicable.

Clinical details on studied participants are displayed.

$p$ Values describe differences between NMOSD and RRMS vs HCs.

time of $1,671.0 \pm 49.3 \mathrm{~ms}$ (range 1,609.5-1753.5 ms) of periependymal regions around the cerebral aqueduct.

T1 relaxation time of periependymal regions in patients with NMOSD

Table 3 and figure 3 give an overview of all results. In comparison to HCs, we observed comparable mean $\mathrm{T} 1$ relaxation time of periependymal regions around the lateral $(p=0.557)$, third $(p=0.773)$, and fourth ventricles $(p=0.372)$, as well as around the cerebral aqueduct $(p=0.754)$.

T1 relaxation time of periependymal regions in patients with MS

Table 3 and figure 3 give an overview of all results. In comparison to HCs, we observed longer T1 relaxation times of periependymal regions around the lateral $(p=0.043)$, third
( $p=0.027)$, and fourth ventricles $(p=0.013)$, as well as around the cerebral aqueduct $(p=0.005)$.

In comparison to NMOSD, we observed longer T1 relaxation times of periependymal regions around the lateral $(p=0.056)$, third $(p=0.173)$, and fourth ventricles $(p=0.016)$, as well as around the cerebral aqueduct $(p=0.048)$.

\section{Discussion}

In this study, we aimed to explore occult brain damage in normal-appearing periependymal regions that are characterized by a high expression of $A Q P 4$ water channels in patients with AQP4 antibody-positive NMOSD by quantitative MRI with a high signal-to-noise ratio at 7 Tesla. We found that $\mathrm{T} 1$

Table $3 \mathrm{~T} 1$ of periependymal regions in patients with NMOSD or RRMS and HCS

\begin{tabular}{|c|c|c|c|}
\hline & $\mathrm{HC}$ & NMOSD & MS \\
\hline $\begin{array}{l}\text { Lateral ventricle (T1 in ms, mean } \pm S D \text {, range, } p \\
\text { value) }\end{array}$ & $\begin{array}{l}1,355.6 \pm 49.3 \\
1,296.5-1,472.4\end{array}$ & $\begin{array}{l}1,354.4 \pm 82.1 ; 1,269.7-1,568.5 \\
p=0.557\end{array}$ & $\begin{array}{l}1,405.6 \pm 61.9 \\
1,331.3-1,508.9 \\
p=\mathbf{0 . 0 4 3}\end{array}$ \\
\hline $\begin{array}{l}\text { Lateral ventricle GM (T1 in ms, mean } \pm S D \text {, range, } p \\
\text { value) }\end{array}$ & $\begin{array}{l}1772.9 \pm 23.1 \\
1741.9-1819.5\end{array}$ & $\begin{array}{l}1769.5 \pm 45.3 ; 1,679.9-1831.1 \\
p=0.838\end{array}$ & $\begin{array}{l}1816.5 \pm 34.4 \\
1776.8-1877.6 \\
\boldsymbol{p}=\mathbf{0 . 0 0 7}\end{array}$ \\
\hline $\begin{array}{l}\text { Lateral ventricle WM (T1 in ms, mean } \pm S D \text {, range, } p \\
\text { value) }\end{array}$ & $\begin{array}{l}1,220.9 \pm 53.8 \\
1,166.8-1,358.6\end{array}$ & $\begin{array}{l}1,224.8 \pm 77.6 ; 1,162.9-1,441.1 \\
p=0.809\end{array}$ & $\begin{array}{l}1,261.5 \pm 64.6 \\
1,210.0-1,393.4 \\
p=0.070\end{array}$ \\
\hline Third ventricle ( $T 1$ in ms, mean $\pm S D$, range, $p$ value) & $\begin{array}{l}1,534.7 \pm 47.5 \\
1,470.0-1,597.1\end{array}$ & $\begin{array}{l}1,545.1 \pm 103.8 ; 1,414.56-1773.81 \\
p=0.773\end{array}$ & $\begin{array}{l}1,606.8 \pm 58.4 \\
1,534-1711.2 \\
\boldsymbol{p}=\mathbf{0 . 0 2 7}\end{array}$ \\
\hline $\begin{array}{l}\text { Fourth ventricle (T1 in ms, mean } \pm \text { SD, range, } p \\
\text { value) }\end{array}$ & $\begin{array}{l}1,359.2 \pm 25.5 \\
1,322.9-1,409.9\end{array}$ & $\begin{array}{l}1,345.6 \pm 40.3 ; 1,292.2-1,423.6 \\
p=0.372\end{array}$ & $\begin{array}{l}1,397.0 \pm 38.2 \\
1,353.3-1,450.3 \\
\boldsymbol{p}=\mathbf{0 . 0 1 3}\end{array}$ \\
\hline $\begin{array}{l}\text { Cerebral aqueduct (T1 in ms, mean } \pm \text { SD, range, } p \\
\text { value) }\end{array}$ & $\begin{array}{l}1,671.0 \pm 49.32 \\
1,609.5-1753.5\end{array}$ & $\begin{array}{l}1,680.5 \pm 82.45 ; 1,544.8-1830.1 ; p= \\
0.754\end{array}$ & $\begin{array}{l}1757.1 \pm 57.1 \\
1,698.1-1846.3 \\
p=\mathbf{0 . 0 0 5}\end{array}$ \\
\hline
\end{tabular}

Abbreviations: $\mathrm{NMOSD}=$ neuromyelitis optica spectrum disorder; RRMS = relapsing-remitting $\mathrm{MS} ; \mathrm{HC}=$ healthy control; $\mathrm{GM}=$ gray matter; $\mathrm{WM}=$ white matter. T1 relaxation times of periependymal regions in patients with NMOSD or RRMS and HCs are displayed. $p$ Values describe differences between NMOSD and RRMS vs HCS. $p$ values $<0.05$ are highlighted in bold. 


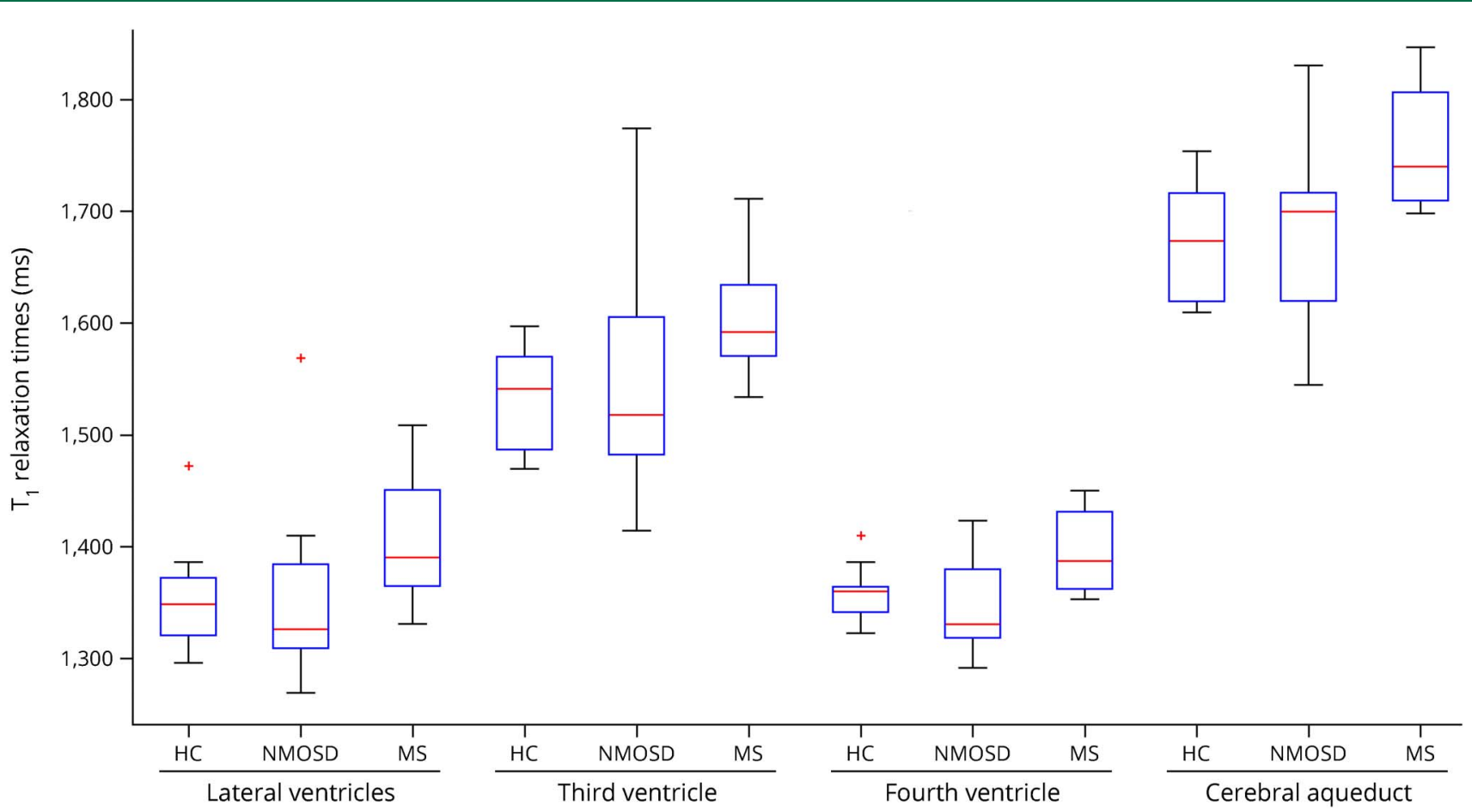

Box plots of mean T1 values within periependymal regions around the lateral ventricles, the third ventricle, the cerebral aqueduct, and the fourth ventricle are displayed.

relaxation times in normal-appearing periependymal regions did not differ between patients with NMOSD and HCs.

The $\mathrm{T} 1$ relaxation time is predominantly influenced by structural changes or damage and free protons found in, e.g., inflammatory edema. ${ }^{19}$ In other words, both structural damage and edema lead to a prolonged $\mathrm{T} 1 \mathrm{in}$ comparison to healthy brain tissue. By applying quantitative T1 relaxometry at 7 Tesla, one benefits from a substantially increased signal-to-noise ratio and hence increased sensitivity for changes in T1. Thus, T1 relaxation times within the range of those found in HCs argue against the existence of structural damage or edema within the analyzed periependymal regions in patients with AQP4 antibody-positive NMOSD.

Indeed, most previous MRI studies have described no or more focal lesions within the NMOSD brain. ${ }^{6,8,9,20}$ Although NMOSD-specific lesions are often found in AQP4-rich periependymal regions of diencephalic structures, the area postrema, the thalamus, the hypothalamus, the corpus callosum, or the periventricular white matter, ${ }^{6}$ there is only little evidence on a more diffuse or occult damage in those regions. ${ }^{21}$

Several studies have investigated a diffuse or occult damage within the normal-appearing white matter (NAWM) of patients with NMOSD by applying different MRI techniques.

Proton MR spectroscopy (MRS) is a widely applied method used to assess metabolic alterations and the integrity of axonal and neuronal structures. In NMOSD, normal $\mathrm{N}$-acetylaspartic acid (NAA), creatine, and choline levels were reported within the NAWM, arguing against occult axonal or neuronal damage, inflammation, and gliosis. ${ }^{22-24} \mathrm{~A}$ recent well-powered MRS study confirmed these findings by reporting normal NAA levels in NMOSD. ${ }^{25}$

Furthermore, diffusion tensor imaging (DTI) - that is sensitive to structural changes- has been performed in NMOSD. DTI data on the NAWM in NMOSD are inconclusive. On the one hand, no DTI abnormalities were reported within brain regions, ${ }^{26}$ except for the visual pathway where Wallerian degeneration may occur after optic neuritis. ${ }^{27,28}$ Contrarily, other research groups have observed fractional anisotropy changes - a marker of the structural integrity - within the NAWM of patients with NMOSD. ${ }^{29,30}$ Such DTI abnormalities were, however, rather mild and not as severe as in patients with $\mathrm{MS}^{31}$

Another technique to analyze a more global brain pathology is structural volumetric imaging. Although some groups reported no ${ }^{26}$ or only mild brain volume changes in NMOSD, ${ }^{32,33}$ others observed white matter volume loss ${ }^{34}$ but not cortical gray matter volume loss, which contrast atrophy measures in MS. ${ }^{35}$

Finally, a 7T MRI study on the periventricular venous density in patients with NMOSD did not report changes in venous visibility on highly resolving $\mathrm{T} 2{ }^{*} \mathrm{w}$ images arguing against a widespread hypometabolism in NMOSD. ${ }^{36}$ 
All these studies indicate that occult or diffuse brain damage either is absent or only plays a minor role in the pathophysiology of NMOSD, ${ }^{21-31}$ which may result in less brain atrophy in comparison to MS. ${ }^{26,32-35}$ Of note, this assumption is well in line with the clinical presentation of NMOSD. ${ }^{2,5}$ The latter is often characterized by a relapsing-remitting or monophasic disease course. A (secondary) progressive disease course is rare in NMOSD. ${ }^{2,5}$

In contrast to NMOSD, we clearly observed prolonged $\mathrm{T} 1$ relaxation times in patients with MS, especially within the periependymal thalamus and caudate nuclei. Those results may either reflect diffuse normal-appearing white and gray matter damage in MS as indicated by MRS, ${ }^{25} \mathrm{DTI}^{31}{ }^{31}$ volumetric $^{37}$ or quantitative T1 studies, ${ }^{38}$ or is caused by small lesions within, e.g., the thalamus that are not obviously seen on conventional MRI. ${ }^{39}$

Our study is not free of limitations. Although all lesion masks and periependymal regions of interest (ROIs) were best visually corrected with high diligence, we cannot exclude minor misclassifications and partial volume effects. Periependymal ROIs were, however, created with a $1-\mathrm{mm}$ "security" distance around the ventricles. Thus, partial volume effects should not have a relevant effect on this work. In addition, the number of analyzed patients with MS was relatively low.

Our findings of normal $\mathrm{T} 1$ relaxation times in normalappearing lesion-free periependymal regions of patients with NMOSD argue against a severe diffuse or occult brain damage even in AQP4-rich brain regions, which is well in line with the literature, the clinical phenotype of NMOSD, and in contrast to MS. Future work needs to ask, what pathophysiologic processes exactly drive lesion formation in AQP4 antibodypositive human NMOSD. ${ }^{40}$

\section{Study funding}

This study was supported by the Guthy-Jackson Charitable Foundation and Deutsche Forschungsgemeinschaft (DFG Exc 257).

\section{Disclosure}

B. Pasquier received travel funding from the ECTRIMS. N. Borisow and L. Rasche report no disclosures. J. BellmannStrobl received speaker honoraria and travel funding from Bayer, Sanofi-Aventis/Genzyme, Merck, and Teva. K. Ruprecht served on the scientific advisory boards of SanofiAventis/Genzyme, Novartis, and Roche; received travel funding and/or speaker honoraria from Bayer, Biogen, Merck Serono, Sanofi-Aventis/Genzyme, Teva, Novartis, and Guthy-Jackson Charitable Foundation; served as academic editor of PLoS One; received publishing royalties from Elsevier; received research support from Novartis, Merck Serono, and German Ministry of Education and Research. T. Niendorf received travel funding from Siemens; served as guest editor for MR Materials in Physics,
Biology and Medicine; is founder and CEO of MRI Tools; and received research support from Siemens. T.J. Derfuss served on the scientific advisory boards of Biogen, Novartis, Genzyme, Merck, Bayer, Octapharma, GeNeuro, Roche, Actelion, and Celgene; received travel and speaker honoraria from Bayer, Biogen, Merck, Novartis, Genzyme, and Roche; is a member of the editorial board of PLOS ONE; is a member of the steering committee of Mitsubishi Pharma and GeNeuro; is on the speaker bureau of Biogen, Novartis, and Merck; is on the executive board of ECTRIMS; and received research support from Novartis, Biogen, Swiss National Foundation, and Swiss MS Society; his spouse is an employee and holds stock options in Novartis. J. Wuerfel served on the scientific advisory boards of Novartis, Biogen, Genzyme, Teva, and Roche; received travel funding and/or speaker honoraria from Novartis, Bayer, and Biogen; has been employed as CEO at MIAC $A G$; and received research support from the German Ministry of Education and Research and German Ministry of Economy. F. Paul served on the scientific advisory boards of Novartis and MedImmune; received travel funding and/or speaker honoraria from Bayer, Novartis, Biogen, Teva, Sanofi-Aventis/Genzyme, Merck Serono, Alexion, Chugai, MedImmune, and Shire; is an associate editor of Neurology: Neuroimmunology \& Neuroinflammation; is an academic editor of PLoS ONE; consulted for Sanofi Genzyme, Biogen, MedImmune, Shire, and Alexion; received research support from Bayer, Novartis, Biogen, Teva, Sanofi-Aventis/Geynzme, Alexion, and Merck Serono; and received research support from the German Research Council, Werth Stiftung of the City of Cologne, German Ministry of Education and Research, Arthur Arnstein Stiftung Berlin, EU FP7 Framework Program, Arthur Arnstein Foundation Berlin, Guthy-Jackson Charitable Foundation, and NMSS. T. Sinnecker received travel funding and/or speaker honoraria from Actelion, Roche, and Biogen and has been employed by MIAC. Go to Neurology.org/NN for full disclosures.

\section{Publication history}

Received by Neurology: Neuroimmunology \& Neuroinflammation September 4, 2018. Accepted in final form November 26, 2018.

\begin{tabular}{|c|c|c|c|}
\hline Name & Location & Role & Contribution \\
\hline $\begin{array}{l}\text { Baptiste } \\
\text { Pasquier }\end{array}$ & $\begin{array}{l}\text { University Hospital and } \\
\text { University of Basel, Basel, } \\
\text { Switzerland }\end{array}$ & Author & $\begin{array}{l}\text { Analyzed and } \\
\text { interpreted the data, } \\
\text { drafted the } \\
\text { manuscript, and } \\
\text { revised the } \\
\text { manuscript }\end{array}$ \\
\hline $\begin{array}{l}\text { Nadja } \\
\text { Borisow, MD }\end{array}$ & $\begin{array}{l}\text { Charité-Universitätsmedizin } \\
\text { Berlin, Berlin, Germany }\end{array}$ & Author & $\begin{array}{l}\text { Major role in the } \\
\text { acquisition of data } \\
\text { and revised the } \\
\text { manuscript for } \\
\text { intellectual content }\end{array}$ \\
\hline
\end{tabular}

Continued 
Appendix (continued)

\begin{tabular}{|c|c|c|c|}
\hline Name & Location & Role & Contribution \\
\hline $\begin{array}{l}\text { Ludwig } \\
\text { Rasche, MD }\end{array}$ & $\begin{array}{l}\text { Charité-Universitätsmedizin } \\
\text { Berlin, Berlin, Germany }\end{array}$ & Author & $\begin{array}{l}\text { Major role in the } \\
\text { acquisition of data } \\
\text { and revised the } \\
\text { manuscript for } \\
\text { intellectual content }\end{array}$ \\
\hline $\begin{array}{l}\text { Judith } \\
\text { Bellmann- } \\
\text { Strobl, MD }\end{array}$ & $\begin{array}{l}\text { Charité-Universitätsmedizin } \\
\text { Berlin, Berlin, Germany }\end{array}$ & Author & $\begin{array}{l}\text { Major role in the } \\
\text { acquisition of data } \\
\text { and revised the } \\
\text { manuscript for } \\
\text { intellectual content }\end{array}$ \\
\hline $\begin{array}{l}\text { Klemens } \\
\text { Ruprecht, MD }\end{array}$ & $\begin{array}{l}\text { Charité-Universitätsmedizin } \\
\text { Berlin, Berlin, Germany }\end{array}$ & Author & $\begin{array}{l}\text { Acquisition of data, } \\
\text { designed and } \\
\text { conceptualized the } \\
\text { study, and revised the } \\
\text { manuscript for } \\
\text { intellectual content }\end{array}$ \\
\hline $\begin{array}{l}\text { Thoralf } \\
\text { Niendorf, MD, } \\
\text { PHD }\end{array}$ & $\begin{array}{l}\text { Max Delbrück Center for } \\
\text { Molecular Medicine in the } \\
\text { Helmholtz Association, } \\
\text { Berlin, Germany }\end{array}$ & Author & $\begin{array}{l}\text { Designed and } \\
\text { conceptualized the } \\
\text { study and revised the } \\
\text { manuscript for } \\
\text { intellectual content }\end{array}$ \\
\hline $\begin{array}{l}\text { Tobias J. } \\
\text { Derfuss, MD }\end{array}$ & $\begin{array}{l}\text { University Hospital and } \\
\text { University of Basel, Basel, } \\
\text { Switzerland }\end{array}$ & Author & $\begin{array}{l}\text { Designed and } \\
\text { conceptualized the } \\
\text { study and revised the } \\
\text { manuscript for } \\
\text { intellectual content }\end{array}$ \\
\hline $\begin{array}{l}\text { Jens Wuerfel, } \\
\text { MD }\end{array}$ & $\begin{array}{l}\text { Medical Image Analysis } \\
\text { Center AG, Basel, } \\
\text { Switzerland }\end{array}$ & Author & $\begin{array}{l}\text { Major role in the } \\
\text { acquisition of data, } \\
\text { interpreted the data, } \\
\text { designed and } \\
\text { conceptualized the } \\
\text { study, and revised the } \\
\text { manuscript for } \\
\text { intellectual content }\end{array}$ \\
\hline $\begin{array}{l}\text { Friedemann } \\
\text { Paul, MD }\end{array}$ & $\begin{array}{l}\text { Charité-Universitätsmedizin } \\
\text { Berlin, Berlin, Germany }\end{array}$ & Author & $\begin{array}{l}\text { Major role in the } \\
\text { acquisition of data, } \\
\text { interpreted the data, } \\
\text { designed and } \\
\text { conceptualized the } \\
\text { study, and revised the } \\
\text { manuscript for } \\
\text { intellectual content }\end{array}$ \\
\hline $\begin{array}{l}\text { Tim } \\
\text { Sinnecker, } \\
\text { MD }\end{array}$ & $\begin{array}{l}\text { University Hospital and } \\
\text { University of Basel, Basel, } \\
\text { Switzerland }\end{array}$ & Author & $\begin{array}{l}\text { Major role in the } \\
\text { acquisition of data, } \\
\text { interpreted the data, } \\
\text { designed and } \\
\text { conceptualized the } \\
\text { study, drafted the } \\
\text { manuscript, and } \\
\text { revised the } \\
\text { manuscript for } \\
\text { intellectual content }\end{array}$ \\
\hline
\end{tabular}

\section{References}

1. Wingerchuk DM, Banwell B, Bennett JL, et al. International consensus diagnostic criteria for neuromyelitis optica spectrum disorders. Neurology 2015;85:177-189.

2. Jarius S, Wildemann B, Paul F. Neuromyelitis optica: clinical features, immunopathogenesis and treatment. Clin Exp Immunol 2014;176:149-164.

3. Papadopoulos MC, Verkman AS. Aquaporin water channels in the nervous system. Nat Rev Neurosci 2013;14:265-277.

4. Jarius S, Paul F, Franciotta D, et al. Mechanisms of disease: aquaporin-4 antibodies in neuromyelitis optica. Nat Clin Pract Neurol 2008;4:202-214.

5. Jarius S, Ruprecht K, Wildemann B, et al. Contrasting disease patterns in seropositive and seronegative neuromyelitis optica: a multicentre study of 175 patients. J Neuroinflammation 2012;9:14

6. Kim HJ, Paul F, Lana-Peixoto MA, et al. MRI characteristics of neuromyelitis optica spectrum disorder: an international update. Neurology 2015;84:1165-1173.

7. Oertel FC, Kuchling J, Zimmermann H, et al. Microstructural visual system changes in AQP4-antibody-seropositive NMOSD. Neurol Neuroimmunol Neuroinflamm 2017; 4:e334. doi: 10.1212/NXI.0000000000000541.

8. Popescu BFG, Lennon VA, Parisi JE, et al. Neuromyelitis optica unique area postrema lesions: nausea, vomiting, and pathogenic implications. Neurology 2011;76:1229-1237.

9. Pittock SJ, Weinshenker BG, Lucchinetti CF, Wingerchuk DM, Corboy JR, Lennon VA. Neuromyelitis optica brain lesions localized at sites of high aquaporin 4 expression. Arch Neurol 2006;63:964-968.
10. Pittock SJ, Lennon VA, Krecke K, Wingerchuk DM, Lucchinetti CF, Weinshenker BG. Brain abnormalities in neuromyelitis optica. Arch Neurol 2006;63:390-396.

11. Trebst C, Jarius S, Berthele A, et al. Update on the diagnosis and treatment of neuromyelitis optica: recommendations of the neuromyelitis optica study group (NEMOS). J Neurol 2014;261:1-16.

12. Wingerchuk DM, Lennon VA, Pittock SJ, Lucchinetti CF, Weinshenker BG. Revised diagnostic criteria for neuromyelitis optica. Neurology 2006;66:1485-1489.

13. Kuchling J, Brandt AU, Paul F, Scheel M. Diffusion tensor imaging for multilevel assessment of the visual pathway: possibilities for personalized outcome prediction in autoimmune disorders of the central nervous system. EPMA J 2017;8:279-294.

14. Sinnecker T, Mittelstaedt P, Dörr J, et al. Multiple sclerosis lesions and irreversible brain tissue damage: a comparative ultrahigh-field strength magnetic resonance imaging study. Arch Neurol 2012;69:739-745.

15. Kalluri SR, Illes Z, Srivastava R, et al. Quantification and functional characterization of antibodies to native aquaporin 4 in neuromyelitis optica. Arch Neurol 2010;67:1201-1208.

16. Jarius S, Probst C, Borowski K, et al. Standardized method for the detection of antibodies to aquaporin- 4 based on a highly sensitive immunofluorescence assay employing recombinant target antigen. J Neurol Sci 2010;291:52-56.

17. Waters P, Reindl M, Saiz A, et al. Multicentre comparison of a diagnostic assay: aquaporin-4 antibodies in neuromyelitis optica. J Neurol Neurosurg Psychiatry 2016, 87:1005-1015.

18. Marques JP, Kober T, Krueger G, van der Zwaag W, Van de Moortele PF, Gruetter R. MP2RAGE, a self bias-field corrected sequence for improved segmentation and T1mapping at high field. Neuroimage 2010;49:1271-1281.

19. Sinnecker T, Granziera C, Wuerfel J, Schlaeger R. Future brain and spinal cord volumetric imaging in the clinic for monitoring treatment response in MS. Curr Treat Options Neurol 2018;20:17

20. Jarius S, Ruprecht K, Kleiter I, et al. MOG-IgG in NMO and related disorders: a multicenter study of 50 patients. Part 2: epidemiology, clinical presentation, radiological and laboratory features, treatment responses, and long-term outcome. J Neuroinflammation 2016;13:280

21. Kremer S, Renard F, Achard S, et al. Use of advanced magnetic resonance imaging techniques in neuromyelitis optica spectrum disorder. JAMA Neurol 2015;72:815-822.

22. Aboul-Enein F, Krssák M, Höftberger R, Prayer D, Kristoferitsch W. Diffuse white matter damage is absent in neuromyelitis optica. AJNR Am J Neuroradiol 2010;31:76-79.

23. Bichuetti DB, Rivero RL, de Oliveira EM, et al. White matter spectroscopy in neuromyelitis optica: a case control study. J Neurol 2008;255:1895-1899.

24. de Seze J, Blanc F, Kremer S, et al. Magnetic resonance spectroscopy evaluation in patients with neuromyelitis optica. J Neurol Neurosurg Psychiatry 2010;81: 409-411.

25. Duan Y, Liu Z, Liu Y, et al. Metabolic changes in normal-appearing white matter in patients with neuromyelitis optica and multiple sclerosis: a comparative magnetic resonance spectroscopy study. Acta Radiol 2017;58:1132-1137.

26. Finke C, Heine J, Pache F, et al. Normal volumes and microstructural integrity of deep gray matter structures in AQP4+ NMOSD. Neurol Neuroimmunol Neuroinflamm 2016;3:e229. doi: 10.1212/NXI.0000000000000541.

27. Pache F, Zimmermann $\mathrm{H}$, Finke $\mathrm{C}$, et al. Brain parenchymal damage in neuromyelitis optica spectrum disorder-a multimodal MRI study. Eur Radiol 2016;26:4413-4422.

28. Kuchling J, Backner Y, Oertel FC, et al. Comparison of probabilistic tractography and tract-based spatial statistics for assessing optic radiation damage in patients with autoimmune inflammatory disorders of the central nervous system. Neuroimage Clin 2018;19:538-550

29. Kimura MCG, Doring TM, Rueda FC, Tukamoto G, Gasparetto EL. In vivo assessment of white matter damage in neuromyelitis optica: a diffusion tensor and diffusion kurtosis MR imaging study. J Neurol Sci 2014;345:172-175.

30. Liu Y, Duan Y, He Y, et al. A tract-based diffusion study of cerebral white matter in neuromyelitis optica reveals widespread pathological alterations. Mult Scler 2012;18:1013-1021.

31. Kim SH, Kwak K, Hyun JW, et al. Diffusion tensor imaging of normal-appearing white matter in patients with neuromyelitis optica spectrum disorder and multiple sclerosis. Eur J Neurol 2017;24:966-973.

32. Liu Y, Wang J, Daams M, et al. Differential patterns of spinal cord and brain atrophy in NMO and MS. Neurology 2015;84:1465-1472.

33. Hyun JW, Park G, Kwak K, et al. Deep gray matter atrophy in neuromyelitis optica spectrum disorder and multiple sclerosis. Eur J Neurol 2017;24:437-445.

34. Blanc F, Noblet V, Jung B, et al. White matter atrophy and cognitive dysfunctions in neuromyelitis optica. PLoS One 2012;7:e33878

35. Chanson JB, Lamy J, Rousseau F, et al. White matter volume is decreased in the brain of patients with neuromyelitis optica. Eur J Neurol 2013;20:361-367.

36. Schumacher S, Pache F, Bellmann-Strobl J, et al. Neuromyelitis optica does not impact periventricular venous density versus healthy controls: a 7.0 Tesla MRI clinical study. MAGMA 2016;29:535-541.

37. Solomon AJ, Watts R, Dewey BE, Reich DS. MRI evaluation of thalamic volume differentiates MS from common mimics. Neurol Neuroimmunol Neuroinflamm 2017;4:e387. doi: 10.1212/NXI.0000000000000541.

38. Vrenken H, Geurts JJG, Knol DL, et al. Whole-brain T1 mapping in multiple sclerosis: global changes of normal-appearing gray and white matter. Radiology 2006;240: 811-820.

39. Harrison DM, Oh J, Roy S, et al. Thalamic lesions in multiple sclerosis by $7 \mathrm{~T}$ MRI: clinical implications and relationship to cortical pathology. Mult Scler 2015;21: 1139-1150.

40. Takeshita Y, Obermeier B, Cotleur AC, et al. Effects of neuromyelitis optica-IgG at the blood-brain barrier in vitro. Neurol Neuroimmunol Neuroinflamm 2016;4:e311. doi: 10.1212/NXI.0000000000000541. 


\section{Neurology \\ Neuroimmunology \& Neuroinflammation}

\section{Quantitative 7T MRI does not detect occult brain damage in neuromyelitis optica Baptiste Pasquier, Nadja Borisow, Ludwig Rasche, et al. \\ Neurol Neuroimmunol Neuroinflamm 2019;6; \\ DOI 10.1212/NXI.0000000000000541}

This information is current as of March 7, 2019

\section{Updated Information \& Services}

References

Subspecialty Collections

Permissions \& Licensing

Reprints including high resolution figures, can be found at: http://nn.neurology.org/content/6/3/e541.full.html

This article cites 40 articles, 3 of which you can access for free at: http://nn.neurology.org/content/6/3/e541.full.html\#\#ref-list-1

This article, along with others on similar topics, appears in the following collection(s):

All Demyelinating disease (CNS)

http://nn.neurology.org//cgi/collection/all_demyelinating_disease_cns Devic's syndrome

http://nn.neurology.org//cgi/collection/devics_syndrome

MRI

http://nn.neurology.org//cgi/collection/mri

Multiple sclerosis

http://nn.neurology.org//cgi/collection/multiple_sclerosis

Information about reproducing this article in parts (figures,tables) or in its entirety can be found online at:

http://nn.neurology.org/misc/about.xhtml\#permissions

Information about ordering reprints can be found online: http://nn.neurology.org/misc/addir.xhtml\#reprintsus

Neurol Neuroimmunol Neuroinflamm is an official journal of the American Academy of Neurology.

Published since April 2014, it is an open-access, online-only, continuous publication journal. Copyright

Copyright (C) 2019 The Author(s). Published by Wolters Kluwer Health, Inc. on behalf of the American

Academy of Neurology.. All rights reserved. Online ISSN: 2332-7812.

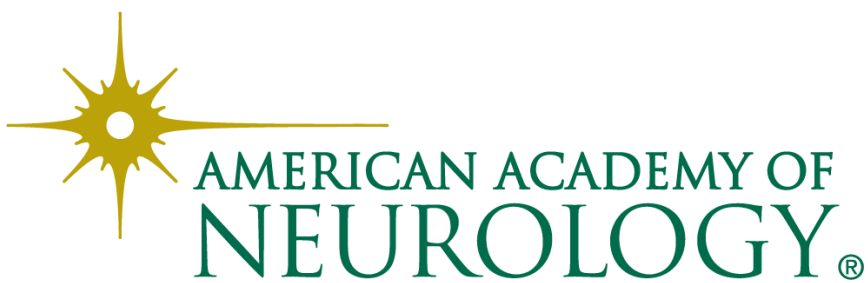

